\title{
PENINGKATAN KOMPETENSI GURU DALAM PEMBUATAN BAHAN AJAR MENGGUNAKAN MEDIA PEMBELAJARAN SMART LEARNING DI KECAMATAN SEMBAWA SUMATERA SELATAN
}

\author{
Terttiaavini $^{1)}$, Tedy Setiawan Saputra ${ }^{2)}$, Anisa Fitriani ${ }^{3)}$ \\ 1) Program studi Sistem Informasi Universitas Indo Global Mandiri \\ 2) Program studi Magister Manjemen Universitas Indo Global Mandiri \\ 3) Program studi Teknik Informatika Universitas Indo Global Mandiri \\ Jl. Jend. Sudirman No 629 KM 4 Palembang, Kode Pos 30129 \\ Email : $\underline{\text { avini.saputra@uigm.ac.id }}^{1}$, tdyfaith@gmail.com $^{2}$, anisa.fitirani@students.uigm.ac.id $^{3)}$
}

\begin{abstract}
ABSTRAK
Peran Guru sebagai perencana, pelaksana, maupun elevator pembelajaran sangat penting dalam mencerdaskan kehidupan bangsa. Kemampuan Guru dalam menciptakan pembelajaran yang berkualitas sangat menentukan keberhasilan pendidikan bagi Siswa. Namun kendala yang dihadapi Guru di Kecamatan Sembawa Kabupaten Banyuasin Sumatera selatan menyebabkan proses belajar mengajar menjadi tidak maksimal. Permasalahan tersebut antara lain adalah letak sekolah jauh dari tempat tinggal, sering terjadi banjir, tidak tercapainya target penyampaian materi, biaya bimbingan belajar yang mahal dan budaya ortodok orang tua Siswa yang lebih mengutamakan mencari uang dari pada sekolah. Hal tersebut perlu dicarikan solusinya. Pemanfaatan media pembelajaran dengan memanfaatkan software application dapat menciptakan model pembelajaran yang menarik. Model pembelajaran tersebut dinamakan Smart learning. Penerapan Smart learing dapat meningkatkan kompetensi dan kreatifitas guru dalam membuat materi ajar yang menarik dan inovatif. Materi ajar akan direkam dalam CD denganbentuk visualisasi dan audio dengan suara asli gurunya sehingg dapat memberikan efek psikologi yang baik bagi proses belajar Siswa. Selain itu Guru juga dapat memberikan soft skill untuk memotivasi dan mengarahkan Siswa memiliki kepribadian yang baik dan cerdas.
\end{abstract}

Kata kunci : Kompetensi, Guru, Media pembelajaran, Smart Learning

\section{PENDAHULUAN}

Guru merupakan salah satu komponen manusiawi dalam proses belajar mengajar, yang ikut berperan dalam usaha pembentukan sumber daya manusia yang potensial di bidang pembangunan (Sardiman, 1986). Guru harus memiliki kemampuan inovatif dalam mengembangkan teknik pembelajaran. Peran Guru sangat penting dalam mencerdaskan kehidupan bangsa, sebagai perencana, pelaksana, maupun elevator pembelajaran. Kemampuan Guru dalam menciptakan pembelajaran yang berkualitas sangat menentukan keberhasilan pendidikan bagi Siswa. Berbagai pihak turut serta membantu untuk meningkatkan kompetensi Guru, antara lain dari tingkat Universitas. Melalui penelitian dan kegiatan pengabdian pada masyarakat, dosen menciptakan cara yang kreatif dan inovatif yang dapat digunakan oleh Guru untuk meningkatkan kemampuan dalam mengembangkan teknik pembelajaran.

Provinsi Sumatera Selatan terdiri dari 12 Kabupaten dan 4 Kotamadya. Daerah yang menjadi sasaran kegiatan pengabdian pada masyarakat ini adalah Kabupaten Banyuasin. Adapun Sekolah tingkat menengah atas (SMA) yang dipilih menjadi pilot project adalah SMAN I Sembawa dan SMKN Tanjung Lago Banyuasin. Jarak tempuh dari kota Palembang ke Kabupaten Banyuasin kurang lebih 40 $\mathrm{km} / \pm 1.5$ jam. Sebagian besar Guru dan Siswa berdomisili di kota Palembang atau perbatasan Banyuasin. Meningkatnya kendaraan di jalur Palembang - Banyuasin sering menyebabkan Guru dan Siswa terlambat datang ke sekolah. Apalagi musim hujan, banjir sering terjadi sehingga kendaraan tidak dapat melewati jalur terebut. Hal tersebut tentunya dapat mengganggu proses belajar mengajar.

Beberapa Kabupaten di Provinsi Sumatera Selatan belum memiliki infrastruktur teknologi informasi yang memadai. Trend penggunaan media pembelajaran elearning, saat ini belum dapat diimplementasikan. Pengembangan media belajar menggunakan konsep elearning tidak dapat memberikan manfaat yang signifikan didaerah tersebut. Selain itu faktor dari Guru yang kurang kreatif 
dalam mengembangkan metode pembelajaran, tidak tercapainya penyampaian materi sesuai dengan standar kurikulum pendidikan, rendahnya tanggung jawab Guru untuk menjalankan visi dan misi pendidikan, juga menjadi penyebab tidak tercapainya target kurikulum pengajaran. Kondisi Siswa sulit untuk mencapai prestasi yang maskimal. Lemahnya pemahaman dan logika penalaran seakan menyimpulkan bahwa Siswa tersebut memiliki iq rendah (bodoh). (Terttiaavini dkk,2016). Sehingga bermunculan Bimbingan Belajar merupakan dampak dari kurang efektifnya proses belajar mengajar disekolah. Tak heran saat ini bimbingan belajar justru banyak di minati oleh Siswa, walaupun dengan biaya mahal. Bagi orang tua Siswa yang memiliki penghasilan lebih, hal tersebut tidak menjadi masalah. Namun bagaimana dengan Siswa dari kalangan keluarga yang berkecukupan. Hal tersebut dapat memberatkan.

Permasalah lainnya adalah Masyarakat Banyuasin kebanyakan memiliki mata pencarian berkebun. Penghasilan dari menyadap karet atau pengumpul biji sawit bukan merupakan mata pencarian yang mencukupi. Harga karet dan biji sawit yang tidak stabil, berpengaruh terhadap penghidupan mereka. Saat kondisi tersebut terjadi, tidak sedikit Siswa tidak masuk sekolah karena harus membantu orangtua mencari nafkah.

Itulah mengapa penyerapan materi ajar oleh Siswa didaerah dan dikota jauh berbeda. Permasalahan tersebut harus dicari solusinya. Jika Guru memiliki motivasi tinggi sebagai agen pengajaran, mengembangkan materi ajar yang lebih kreatif dengan memanfaatkan media pembelajaran baru, diharapkan target pencapaian kurikulum dapat tercapai. Hal ini dapat menjadi solusi mengatasi permasalahan yang selama ini terjadi. Peran serta Dosen sebagai penemu metode baru untuk digunakan oleh guru sangat diharapkan. Solusi yang ditawarkan menilai secara komprehensif dari aspek permasalahan. Memanfaatkan media pembelajaran baru secara maksimal menjadi salah satu solusi yang diusulkan.

Perkembangan teknologi mendorong upaya-upaya pembaharuan untuk memanfaatkan hasilhasil tenologi dalam proses belajar mengajar. Para guru dituntut untuk mampu menggunakan dan mengembangkan media belajar yang tersedia. Menurut Miarso (2004) berpendapat bahwa Media pembelajaran adalah segala sesuatu yang digunakan untuk menyalurkan pesan serta dapat merangsang pikiran, perasaan, perhatian, dan kemauan belajar sehingga dapat mendorong terjadinya proses belajar". Pemakaian media pengajaran dalam proses belajar mengajar dapat membangkitkan keinginan dan minat yang baru, membangkitkan motivasi dan rangsangan kegiatan belajar, dan bahkan membawa pengaruh- pengaruh psikologis terhadap Murid (Omar,1986).

Menurut Kemp dan Dayton (1985) mengidentifikasi Beberapa manfaat menggunakan media pembelajaran yaitu :

1. Penyampaian materi pelajaran dapat diseragamkan;

2. Proses pembelajaran menjadi lebih jelas dan menarik;

3. Proses pembelajaran menjadi lebih interaktif;

4. Efisiensi dalam waktu dan tenaga;

5. Meningkatkan kualitas hasil belajar siswa;

6. Media memungkinkan proses belajar dapat dilakukan dimana saja dan kapan saja;

7. Media dapat menumbuhkan sikap positif siswa terhadap materi dan proses belajar;

8. Merubah peran guru ke arah yang lebih positif dan produktif.

Oleh karena itu pengembangan teknik mengajar dengan pemanfaatan media belajar, menjadi hal yang menarik untuk di terapkan.

Berbagai ide telah diuji cobakan untuk menemukan teknik yang terbaik dalam meningkatkan kemampuan Guru mengajar, seperti pembuatan materi ajar dengan menggunakan aplikasi flash, power point, bloger, elearning dll. Melalui pelatihan-pelatihan yang diadakan di sekolah, menjadi kegiatan yang sangat membantu Guru untuk menambah wawasan mempelajari teknik pengajaran yang baru.

Smart Learing adalah istilah yang dipakai untuk memberikan nama program baru yang diusulkan. Untuk membedakan dengan teknik pembelajaran lain, kiranya perlu digunakan nama baru yang mewakili kegiatan tersebut, agar mudah diingat dan dibedakan dengan metode pembelajaran yang lain.

Smart learing adalah teknik pengembangan materi ajar dengan menghasilkan suatu rekaman materi ajar yang dibuat oleh Guru. Hasil rekaman dapat dipergunakan oleh Siswa sebagai bahan review mata pelajaran dirumah dan sebagai bimbingan belajar dalam mengerjakan soal.

Diharapkkan kegiatan pengabdian kepada Masyarakat ini dapat memberikan banyak manfaat 
bagi Guru dan Siswa untuk mewujudkan pendidikan yang berkualitas, Masyarakat yang cerdas dan bermartabat.

\subsection{Tujuan Penelitian}

Tujuan dari kegiatan pengabdian ini adalah mengadaan program pelatihan bagi Guru SMA untuk meningkatkan kompetensi guru dalam membuat media pembelajaran Smart Learning yang lebih representatif.

\subsection{Manfaat Penelitian}

Adapun manfaat yang akan di diperoleh Guru adalah

1. Meningkatkan kreativitas Guru dalam membuat modul ajar yang lebih representatif.

2. Meningkatkan kompetensi Guru dalam menyusun bahan ajar yang lebih bermutu sesuai dengan standar kurikulum Pendidikan Nasional.

3. Sebagai media pembelajaran yang efektif, karena dapat digunakan sebagai mereview pelajaran disekolah, bagi Siswa yang belum mengerti atau bagi yang tidak masuk sekolah.

4. Mengurangi ketergantungan Siswa untuk mengikuti bimbingan belajar di luar sekolah. Karena materi ajar, soal dan penyelesaianya sudah disediakan didalam CD. Semakin baik dan terstruktur Guru menyusun materi ajar maka penerimaan Siswa pun semakin cepat.

5. Sebagai sarana penyampaian soft skill kepada anak didik.

6. Menambah wawasan Guru dalam penguasaan beberapa aplikasi komputer yang dapat juga digunakan untuk kegunaan lainnya.

\section{METODE PELAKSANAAN PENGABDIAN}

Metode pelaksanan penelitian menguraikan tentang tahapan pelaksaan penelitian dalam menyelesaikan persoalan di Masyarakat. Adapaun tahapan kegiatan penelitian dan penjelasannya dijelaskan pada subab berikut ini.

\subsection{Tahapan Penelitian}

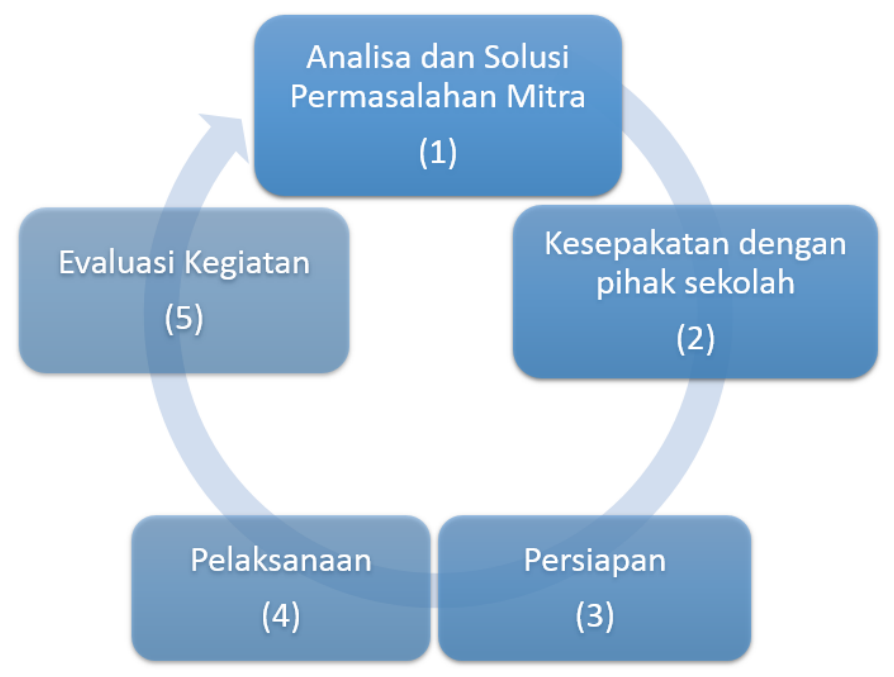

Gambar 1. Tahapan pelaksanaan Penelitian

\subsection{Analisa dan Solusi Permasalahan Mitra}

Solusi yang ditawarkan adalah mengusulkan program pengembangan kompetensi Guru melalui pelatihan membuatan media belajar smart learning dengan memanfaatkan beberapa software application untuk mengahasilkan modul ajar dalam bentuk visualisasi dan audio yang menarik dan bermutu. Melalui progam ini, Guru mendapatkan pelatihan dalam menyusun dan membuat materi ajar menggunakan slide presentasi yang nantinya akan disimpan kedalam CD. 
Selain itu, skill yang diperoleh oleh Guru nantinya dapat juga digunakan untuk keperluan lain, seperti membuat video rekaman yang berasal dari rekaman HP, foto, video dll sehingga dapat menjadi keahlian lainnya diluar tujuan tersebut.

\subsection{Kesepakatan dengan Pihak Sekolah}

Kegiatan selanjutnya adalah membuat kesepakatan dengan pihak sekolah mengenai waktu dan tempat yang tepat untuk melaksanakan kegiatan tersebut. Pihak sekolah berperan menyebarkan informasi kepada beberapa SMA/SMK di Kabupaten Banyuasin dan sekitarnya.

Kapasitas Peserta pelatihan maksimal 45 orang untuk 15 SMA/SMK, dengan perwakilan sekolah maksimal 2 orang. Kegiatan tersebut dilaksanakan selama 3 hari, dari tangal 16 Februari sampai dengan 18 Februari 2015. Pada kegiatan ini yang menjadi sekretariat pelaksana (host) adalah SMAN I Sembawa dan SMKN Tanjung Lago Banyuasin (selaku mitra).

\subsection{Persiapan Pelaksanaan}

Persiapan yang dilakukan untuk pelaksaan kegiatan tersebut adalah menyediakan ruang pelatihan untuk kapasitas 45 orang beserta kelengkapan lainnya seperti infocus, printer, spaker aktif dll. Kegiatan pengabdian ini seharusnya dilakukan di laboratorium komputer (lapkom), karena SMA I Sembawa belum memiliki labkom yang memadai, maka diwajibkan bagi Dosen untuk membawa laptop masing-masing. Modul pelatihan telah disiapkan oleh intruktur sebagai panduan pada saat pelaksanaan. Berikut gambar kondisi pada saat pelatihan.

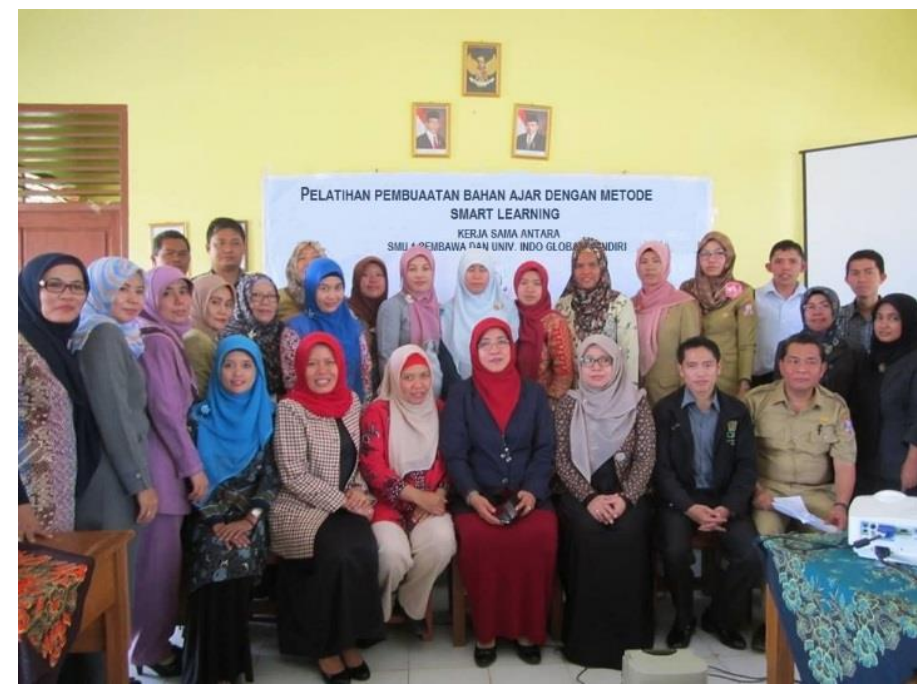

Gambar 2. Kondisi pada saat pelatihan

\subsection{Pelaksanaan Pengabdian}

Pelaksanan penelitian dimulai dari pengenalan beberapa software yang digunakan untuk pelatihan. Apabila Guru tidak memiliki software yang digunakan selama pelatihan, perlu melakukan instalisasi aplikasi terlebih dahulu. Waktu yang diberikan untuk proses install berkisar 30 menit. Selanjutnya dilanjutkan dengan penyampaian materi.

Materi yang pertama adalah pembuatan Bahan ajar dengan menggunakan Ms. Power Point. Materi yang diajarkan tentang pengenalan dasar power point, penyisipan file, animasi dan suara, pemberian efek gerak. Selanjutnya sebagai studi kasus masing-masing guru membuat materi ajar dalam bentuk power point yang menarik sesuai dengan kurikulum.

Materi kedua adalah teknik pembuatan rekaman. Aplikasi yang digunakan adalah Free Screen Video Capture dan Adobe Premiere Pro. Kegunaan dari aplikasi Free Screen Video Capture adalah untuk merekam suara dan aktivitas di monitor. Aplikasi ini akan merekam saat Guru menjelaskan materi di monitor. Alat perekam suara cukup menggunakan speaker yang tersedia dilabtop. Ini berarti pembuatan materi ini tidak membutuhkan penambahan alat rekam baru.

Aplikasi Adobe Premiere Pro digunakan untuk menyusun file power point dalam satu file, sehingga menjadi satu kesatuan modul yang lengkap. Aplikasi ini dapat juga memberikan efek tulisan, background animasi dan lagu, disela-sela file tersebut. Ini akan memberikan kesan pembuat modul yang profesional. Selanjutnya dengan menggunakan aplikasi Winzip, file di compress menjadi ukuran 
yang lebih kecil. Kemudian file tersebut di copy ke dalam CD dengan menggunakan aplikasi Burning Disc.

Guru dapat melakukan proses perekaman sambil menjelaskan materi pada slide power point. Selanjutnya rekaman tersebut disusun dalam suatu file dengan ditambah eksen suara, tulisan/ gambar agar lebih menarik, dan terakhir file dicopy kedalam CD.CD-ROM merupakan akronim dari "compact disc read-only memory" adalah sebuah piringan dari jenis piringan optik (optical disc) yang dapat menyimpan data. CD- ROM juga berarti bahwa CD-ROM drive hanya bisa digunakan untuk membaca sebuah CD saja. http://solusikompi.blogspot.com/2014/10/pengertian-dan-fungsi- cddvd-rom.html. CD akan diberikan kepada masing-masing Siswa. Bahan ajar ini juga dan dapat digunakan untuk Siswa angkatan berikutnya. Contoh bahan ajar yang dibuat oleh guru
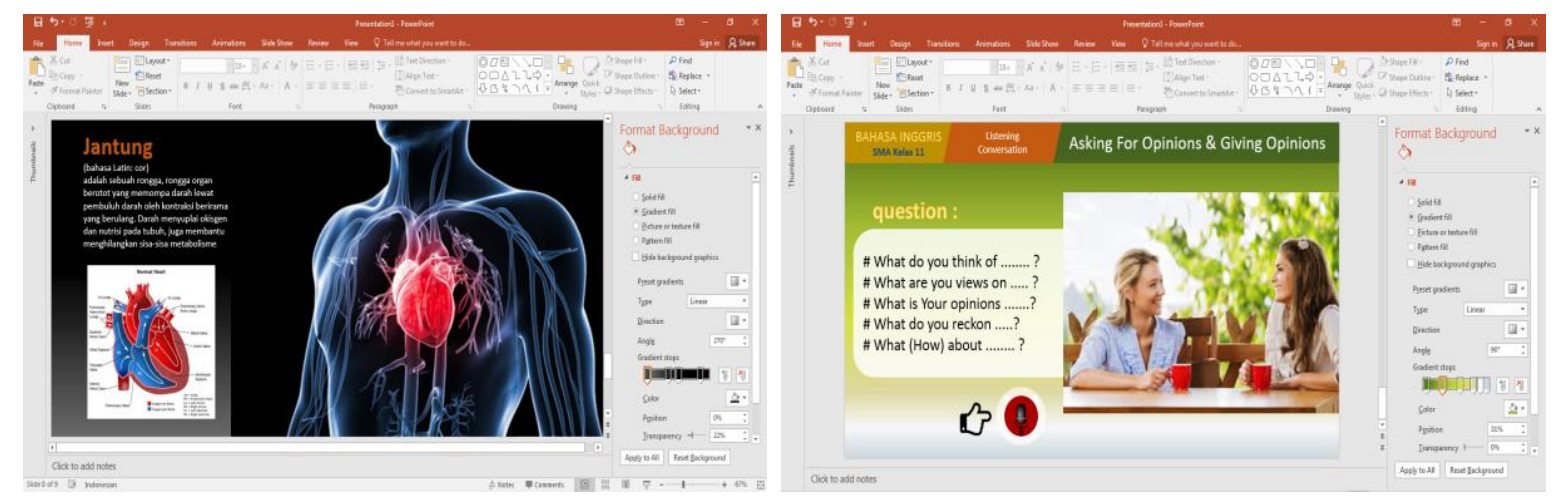

Gambar 3. Bahan ajar untuk mata Pelajaran Biologi dan

Rekaman yang berisi visualisasi dan audio yang berasal dari Guru pengasuh mata ajar memberikan efek penerimaan yang positif bagi Siswa. Siswa merasa sedang mendapatkan les private dari Gurunya sendiri. Siswa juga dapat menggunakannya berulang kali apabila kurang mengerti. Bagi Siswa yang tidak masuk sekolah, tidak akan tertinggal pelajaran karena dapat dipelajarinya dirumah. Selain itu Guru juga dapat memberikan trik cara penyelesaian soal seperti yang diberikan di bimbingan belajar, sehingga Siswa tidak perlu lagi mengambil bimbingan belajar di luar sekolah.

\subsection{Evaluasi kegiatan}

Program smart learing tidak membutuhkan akses internet. Sofware Application yang digunakan umumnya telah tersedia di laptop/komputer. Namun karena tidak mengetahui cara penggunaanya, Sofware Application tersebut tidak dimanfaatkan secara maksimal. Adapun Sofware Application yang digunakan untuk program Smart learning adalah Power Point, Free Screen Video Capture, Adobe Premiere Pro, Winzip dan Burning Disc. Sebagian besar Guru yang ikut pelatihan sudah mengetahui cara menggunakan Aplikasi power point. Namun membuat slide power point yang menarik, dengan menggunakan perpaduan warna, tulisan dan gambar yang kontras dan bergerak, perlu dipelajari kembali agar dapat menghasilkan desain yang lebih baik.

Dari 45 orang Guru yang mewakili, 90\% dari Guru tersebut dapat menerima materi pelatihan dengan baik, sedangkan 5\% lagi penerimaan materi pelatihan masih perlu di ulang kembali, karena faktor usia. Secara teori Guru yag berumur diatas 45 tahun dan jarang menggunakan komputer agak lambat dalam penerimaan materi ajar pelatihan.

\section{HASIL DAN PEMBAHASAN}

Hasil dari kegiatan ini menunjukkan adanya peningkatan pemahaman Guru dalam membuat bahan ajar yang lebih baik dan meningkatkan kemampuan Guru dalam mengimplementasikan bahan ajar ke dalam media pembelajaran yang lebih menarik. Materi ajar yang tersedia dalam CD dapat diulang kembali sehingga dapat meningkatkan pemahaman Siswa terhadap materi yang diajarkan. Berikut gambar Siswa SMA I Sembawa yang sedang mengamati materi ajar yang telah dibuat oleh salah satu guru. 

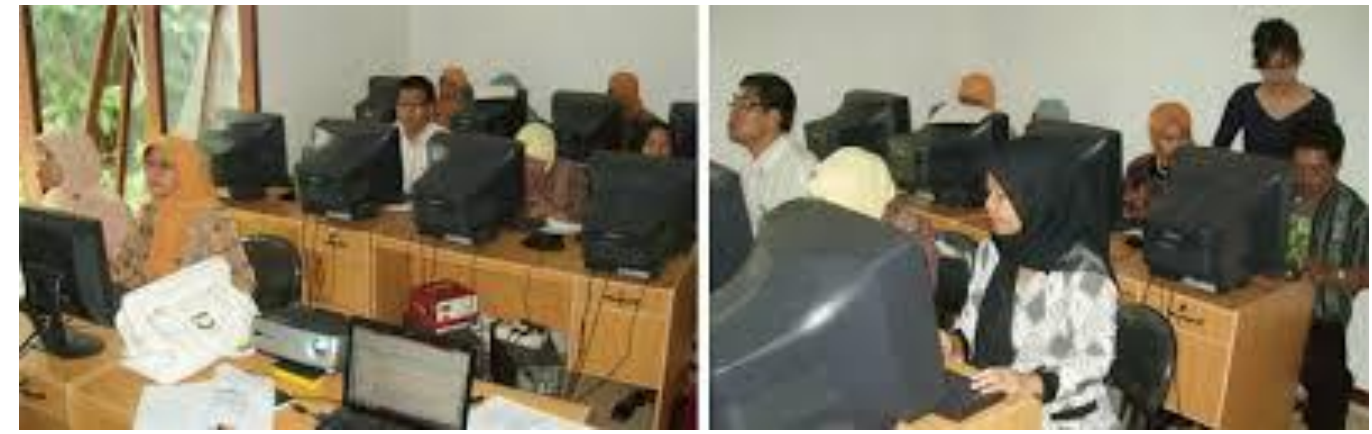

Gambar 4. Suasana Pelatihan

\section{KESIMPULAN}

Dari kegiatan pengabdian kepada Masyarakat yang telah dilakukan, maka dapat disimpulkan beberapa hal, yaitu

1. Metode Smart learning dapat meningkatkan kemampuan Guru dalam membuat bahan ajar yang menarik dan mermutu.

2. Hasil dari kegiatan pengabdian ini tidak hanya meningkatkan kemampuan Guru dalam pembuatan bahan ajar, namun dapat juga di bidang lainnya seperti pada bidang desain dan animasi.

\section{UCAPAN TERIMA KASIH}

Ucapan terimakasih diberikan kepada Universitas Indo Global Mandiri selaku pelindung dalam kegiatan ini, Kepala sekolah dan Guru di SMU 1 Sembawa dan SMKN Tanjung Lago Banyuasin serta Guru-guru di daerah Sembawa yang menjadi peserta pada kegiatan pelatihan ini.

\section{DAFTAR PUSTAKA}

Kemp, Jerold D.1995. The Instructional Design Process. Harper \& Row Publishers. New York Miarso, Yusuhadi. 2004. Menyemai Benih Teknologi Pendidikan. Prenada Media. Jakarta.

Omar, Hamalik. 1986. Media Pendidikan. Alumni. Bandung

Solusi Komputer.2014. Pengertian dan Fungsi CD DVD. Publikasi. http://solusikompi.blogspot.com/2014/10/pengertian-dan-fungsi-cddvdrom.html\#sthash.EQIavvOG.dpuf. 01 April 2015 (10:00)

Terttiaavini, Sumi. amariena Hamim, dan Suzan. Agustri. 2016. Aplikasi Sistem Pakar Penentu Bidang Studi Ditingkat Perguruan Tinggi Berbasis Web. Jurnal Ilmiah Informatika Global 7(1) Des: 67-72 